\title{
USING DIGITAL VIDEO TO RAISE STUDENTS’ MULTI-LITERACIES IN TEACHING ENGLISH FOR YOUNG LEARNERS
}

\author{
Lulus Irawati \\ IKIP PGRI Madiun \\ lulusirawati@gmail.com
}

\begin{abstract}
Teaching English for Young Learners is not as simple as people thought. There are a lot of things to consider. One of them is fostering young learners to be multi-literate. It means that they need to master more than one skill in their life. The skills or abilities are listening, speaking, reading, writing, counting, et cetera, with the sources either from hardcopy (books) or softcopy (internet). Therefore, it is needed a medium to help the young learners to achieve multi-literacies, that it is a digital video. This mini-research aimed to use digital video to raise students' multi-literacies in TEYL, by utilizing descriptive qualitative design. The mini-research was conducted in English course for the age of 9-10 years old. It was done for a month in total of 4 meetings, with duration about 60 minutes. The teacher was successful to use digital video combined with picture series. The students felt happy and interested, since they firstly watched the digital video "sleeping beauty" before being asked to arrange picture series. The teacher also explored some vocabulary in the video and tried to contrast them with reality in surrounding. The kind of activity helped the young learners to communicate cross culturally. In fact, communicating cross culturally was also one of additional skill that indicated the students as multi-literate people. All in all, based on the findings of interview, the researcher also recommended conducting further research.
\end{abstract}

Keywords: Digital video, Multi-literacy, and TEYL

\section{Introduction}

Teaching English for Young Learners is not as simple as people thought. There are a lot of things to be considered. Teaching English for young learners is not only delivering English, as the language itself, but also providing some activities that can stimulate children to raise their whole abilities such reading, writing, counting, spelling, speaking, listening, et cetera. Basically, young learners read, write, count, spell, speak, and listen directly from hard sources namely books or printed materials. These kinds of abilities are, then, called literacy. For young learners, literacy is also realized into their ability of making communication with others. It is similarly found in (http://www.literacytrust.or g.uk/blog/1235) that literacy is the ability to make and communicate meaning from and by the use of a variety of socially contextual symbols. By having their abilities above, young learners can be called as literate people.

Nowadays, being literate is not enough, since there is still one-hidden ability needed. It is the ability to master technology meaning that people, including young learners need to learn how to read, write, and understand things resulted by technology such as reading materials inside computer, writing or typing on computer, and understanding materials taken from internet and computer. These complete and comprehensive abilities 
are called multi-literacies. It was firstly proposed by the New London Group (1996) with the statement that multi-literacy takes into account many linguistic and cultural differences in the society. Moreover, Lankshear, and Knobel (in Guth and Helm, 2011: 43) identified three dimension on the new literacies, namely the operational, cultural, and critical. Operational dimension refers to skills or the ability to search for information, use a particular online tool, share information and resources with others, and multitask. Cultural dimension refers to knowledge in which people can understand appropriate ways of communicating in particular contexts, while critical dimension regards to awareness of power relations involved in the technologies used. In other words, being multi-literate may be seen from these three dimensions; operational, cultural, and critical.

In line with the statements above, it needs media to raise young learners' multiliteracies. The media chosen in this research is digital video combined with picture series. Digital video is selected in relation with the criteria of Lankshear and Nobel (in Guth and Helm, 2011) that the researcher chooses digital video accommodating young learners to search information, understand context or culture, and communicate using the information taken from the video. Moreover, Meixner, et al (2002: 61) proposed principles and consideration for giving children activities related with digital stories namely, teacher help students understand the story, understand the context, use visual tools, use simple vocabulary, express their mind freely, et cetera. Thus, the researcher tries to consider the postulates from Lankshear and Nobel and Meixner, et al to make a procedure of using digital video to raise the children's multiliteracies in which picture series are included as traditional media made from printed pictures in sequence, based on the story of digital video.

All in all, this mini research is conducted in local children English course, owned by village community in Wungu District, Madiun. The researcher chooses the young learners at the age of 9 to 10 (grade 4 and 5 of elementary school). It aims to elaborate the use of digital video combined with picture series to raise young learners' multi-literacies.

\section{Method}

In accordance with the aim of the research to elaborate the use of digital video to raise young learners' multi-literacies, a descriptive qualitative research design was used. The design was greatly appropriate for, it described the phenomena naturally. This research involved 15 students of local children English course-the so-called "Musholla Pintar" facilitating children in surrounding to learn English and read Quran. It is located in Wungu, Madiun. The researcher became an active observer, since the researcher did a 
favor as a volunteer teacher. The lesson plans were made for a month course, in total of 4 meetings. Each meeting spent 60 minutes dividing into pre, main, and closing activities. First, the researcher planned to play digital video in the first and second meeting, in order to make the students accustomed understanding digital visual. Next, the teacher used only traditional media in the third meeting. At last, in the fourth meeting, the teacher utilized both digital video and picture series, in a purpose of raising students' multiliteracies.

Accordingly, the researcher collected data through observing, interviewing, and documenting. The researcher used nonstructured interview with the students, while observing them in the teaching learning process. Then, the researcher documented students score during teaching learning process. The score included students' progress in the form of product and performance. Finally, these data were analyzed with three ways: data reduction, data display, and conclusion drawing (Miles and Huberman, 1994: 10-11).

\section{Result}

The researcher should facilitate all language skills, in these English skills: listening, speaking, reading, and writing. It is based on the young learners' characteristics and language development that they learn a language by listening and repeating while reading and writing come after. Reading and writing are considered to be more difficult than other skills. Therefore, it is necessary for teachers to teach integrated skills by providing activities that promote the students to develop the four English skills simultaneously. Here, as stated above, the researcher chose the fourth and fifth grade students to be the level observed in the use of digital video to raise students' multi-literacies.

There were 4 meetings conducted in this mini research. Each meeting spent 60 minutes that were allocated for, pre activities, main activities, and closing activities. From the first meeting to second meeting, the teacher used digital video with very short duration playing, about 3 to 5 minutes. The digital video contained stories, situation and song. It had not been played digital complete stories yet. In the third meeting, the teacher did not use digital video to teach English, but she used traditional media like pictures, photographs, and models. It was in purpose to raise the students' literacy in balance. At the last meeting, the teacher began to use digital video and picture series, in order to raise their multi-literacies. The implementation is explained clearly below.

The implementation of digital children stories is selected for the purpose to let the students get their literacy understanding more realistic, including culture understanding. First, the researcher as the teacher explored and exposed any vocabulary, ideas that might have relation with the children stories 
approximately for 5 minutes. For instance, if the researcher chose the story entitled 'sleeping beauty', she or he had preliminarily to explore some vocabulary based on the story in order to help the students understand it easier. Listening and speaking actually are started to be taught here. After she or he made sure that the students understood well about those vocabulary, and then she or he could continue to play the digital children story by explaining duration of the story and what they should do during watching it . Next, the teacher raised some questions related to the story namely the name of little girl, the meaning of some vocabulary-sleeping beauty, magic spell, kingdom, palace, etc. and some characters involved there-witch, prince, princess, king and queen, etc. The teacher could write all things related on the board and check the students how to say them. Correct them and train the students how to say in correct way. Later, the teacher informed that the second time of playing the story is in progress in a minute; she or he asked them to watch carefully and started to take a note the content of the story. The teacher checked their understanding through asking what happened in the beginning, the middle, or the end. Finally, playing the digital children story spent 5 minutes.

In addition, there was extended time provided about 10 minutes right after playing the digital story. In ten minutes, the teacher introduced also some cultural issues appearing in the story such as four seasons: winter, spring, autumn, and summer, toast, roasted turkey, candles, present, marriage etc. Although four seasons is natural phenomenon, it is important to be discussed, since the way people dress was different from those who lived in a four-season country and those who lived in a two-season country. Then, the way they act was different too. The teacher explained those things to the young learners such as snowing, a very cold condition, in which snow falls like dust getting thick and thicker. This condition only happened in fourseason countries. It was also discussing how princess in sleeping beauty slept from one season to one season. After the princess woke up, she got married with prince. At marriage party, people liked dancing together in the palace hall, eating a special food-roasted turkey, kissing the bride on cheek to congratulate her, wearing beautiful white gown and many more. Therefore, the students got very clear information anything related with the story.

By understanding all things above, the teacher continued the information by raising the situation contrasted with Indonesian context in 5 minutes. As most students are Javanese, it is necessary to talk about 'mantenan'. Further, the teacher asked them what they usually do in mantenan or what happened there. The students told about their own experiences that they saw marriage party in surrounding. There, they saw the marriage 
couple wearing traditional costumes with various colors of kebaya and beskap, then they begged apologies from their parents by doing the so-called sungkeman-shaking hands warmly one another, or embracing and kissing older people' hands softly and the marriage couple fed nasi kuning each other as symbol of togetherness.

In the next 20 minutes, the teacher provided picture series cards based on the story that were played before. There three bundles of picture series cards. It meant one group consisting of 5 students got a bundle of picture series cards. The teacher asked the students to work in group and arranged the picture series orderly, like what they had watched in the digital video before. The students had to construct a simple sentence of each picture. Further, the students showed and reported their picture series. Later, the teacher gave feedback to the students' work and report.

Moreover, some information could be raised based on the story, that each country has its own tradition and custom. In term of congratulating others, kissing happened between the same gender, man to man, and woman to woman. People in the story always embraced or kissed others as long as they got acquaintance each other. By discussing the content of digital stories, they understood that people are not the same; they may have different color of complexion, caste, social status, ethnics, religion and so on. Then, one of the most important things was tolerating. It means that they have to be respectful and tolerable in any differences whether they like or dislike. To sum up, multi-literacies raised while the students contrasted their customs with Western culture. It gave them experiences although those were only secondhand experiences. It helped them a lot whenever they communicate with other people either in Indonesian or in English.

Based on the implementation above, the researcher as the volunteer teacher felt happy that most students were enthusiastic to follow the story in the video and interested in arranging picture series. Although about 3 students looked confused and less understanding, they still kept trying to do the teacher's instruction. There were 2 students needed special attention, since they often missed the point of discussion. They often said “ma'am..aku lupa artinya kata...”. Therefore, it was necessary for the teacher to check their understanding. Mispronunciation became the most common errors in the classroom. They still read or pronounced exactly like they pronounced bahasa Indonesia. For example, they pronounced 'palace' into pa-las or pa-lace.

Similarly, when the researcher interviewed with the students right after teaching learning process, they faced difficulties in pronouncing and spelling English words. They also admitted being less understanding while watching video, since 
some students were noisy to discuss the coming scene that were shown in the video. In fact, they were all feeling happy and excited to learn English by watching digital stories. The students also stated that they liked the picture series and were helpful to recall their memory of digital stories' content. It was extremely shown in the excerpt "untung ada gambargambar yang berwarna ma'am, terus aku jadi ingat videonya". Further, the combination of understanding the content of digital video and the picture series in sequence automatically raised the students' multi-literacies.

\section{Discussion}

Referring the result above, there are some points found in relation with the use of digital video and picture series for teaching English for young learners (TEYL), in this case the young learners at the age of 9-10 years old. First, the result of mini research showed that the use of digital video and picture series was successful and effective for TEYL, in raising their multi-literacies. In this activity, the students had more space to use their skills or abilities such as, reading, speaking, listening, and many more. They also explored their learning based on not only one dimension, but also another dimension. In other words, they learnt and understood materials in terms of traditional and electronic ones. It was similar with what Robertson, et.al (2012: 84) reported that the digital story gave them more dimensions for teaching and learning; more space for using other skills such as art, film, and photography, and more options to tell stories. Moreover, the students or young learners could also use digital stories as example on how to tell stories. For example, they needed to start telling the stories in the form of picture series from the beginning to the ending, the so-called story plot.

In the second point, the present mini research emerged the students to understand information cross-culturally, since the content of the digital stories was discussed directly and tried to contrast with the real information in surrounding. The students tried to understand and communicate it with their friends. This communication skill was useful when they worked in group arranging picture series and constructing a sentence for each picture. The activity showed that the students blended all four skills of language; listening, speaking, reading, writing. Further, their additional skill like, cultural understanding simultaneously increased. This was in line with Setiasih (2013: 649) reported that the literacy activities and the boundaries of their literacy practices are likely to be influenced by the students' linguistic, cultural, and educational background.

At the last point, based on the interview result, it was seen that the exposure of vocabulary was still needed either in the use of digital video or picture series. Unfortunately, here, the teacher seemed to only explore vocabulary after playing digital 
video, but not in arranging picture series. According to Meixner, et.al (2002: 65-66), the students started the story by looking at the pictures of the story and the vocabulary given based on each picture. Further, it would be better if the teacher provided vocabulary as a clue below each of picture series. In sum, the researcher recommended that the exposure of vocabulary should be done also in arranging picture series. To make the students easier, the other researchers could create more complete picture series attached with clues of vocabulary.

\section{Conclusion}

The digital video and picture series are two simple media effectively applied in teaching English for Young Learners. The impacts are greatly coming out in the surface. This mini-research was shown that the use of digital video and picture series could help to raise students' multi-literacies. While watching digital video as ICT-based media, the students activated their skills of listening and reading. Further, they used their reading and writing skills, while arranging picture series as traditional media. This combination automatically would raise to achieve multi- literacy, although this mini-research was still lack in doing detail of order such as, having very little exposure of vocabulary. In order to do so, the researcher recommends conducting for further research.

\section{References}

Guth, Sarah and Helm, Francesca. 2012. "Developing Multiliteracies through Telecollaboration”. ELT Journal, (6) 42-51.

Meixner, Christ, et al. 2002. Storytelling as vehicle to literacy. In Sollars, Valerie (Eds.), Issues in Multi-literacy. Graz: Council of Europe Publishing.

Miles, Matthew B. and Huberman, Michael. 1994. Qualitative Data Analysis. USA: Sage Publication, Inc.

Robertson, Lorayne, et al. 2012. Thanks for the Assignment: Digital Stories as a Form of Reflective practice. Language and Literacy, Vol. 14, Issue 1, 2012.

Setiasih, Lilis. 2013. The Role of out-ofSchool English Literacy Activities in Promoting Students' English Literacy an Elementary School in Bandung. In Budiman, Manneke and Fauziah, Marti (Eds.), $60^{\text {th }}$ TEFLIN International Conference Proceeding. Jakarta: Universitas Indonesia press.

(http://www.literacytrust.org.uk/blog/1235) retrieved on 12 February 2012 